\title{
Laminaria saccharina photosynthesis measured in situ: photoinhibition and xanthophyll cycle during a tidal cycle
}

\author{
François Gévaert ${ }^{1, *}$, Anne Créach ${ }^{1}$, Dominique Davoult $^{2}$, Aline Migné ${ }^{3}$, \\ Guy Levavasseur ${ }^{2}$, Pierre Arzel ${ }^{4}$, Anne-Catherine Holl ${ }^{1}$, Yves Lemoine ${ }^{1}$ \\ ${ }^{1}$ UMR CNRS 8013 'ELICO', Equipe de Cytophysiologie Végétale et Phycologie, Université des Sciences et Technologies de \\ Lille, Bât SN2, 59655 Villeneuve d'Ascq Cedex, France \\ ${ }^{2}$ UMR CNRS 7127, Université de Paris VI, Station Biologique, 29682 Roscoff Cedex, France \\ ${ }^{3}$ IFR-101, Laboratoire d'Hydrobiologie, Université de Paris VI, 12 rue Cuvier, 75005 Paris, France \\ ${ }^{4}$ Laboratoire côtier DRV/RH, IFREMER, Centre de Brest, BP 70, 29280 Plouzané, France
}

\begin{abstract}
Photosynthetic activity in thalli of Laminaria saccharina (Lamouroux) was followed in situ in the upper subtidal zone of a Northern Brittany rocky shore (Roscoff, France), using a submersible pulse amplitude modulated (PAM) fluorometer. Two fluorescence parameters, the effective quantum yield of photosystem II ( $\left.\Phi_{\text {PSII }}\right)$ and the relative electron transport rate (rETR), were estimated at various stages of a tidal cycle from 10:00 to 18:30 h, and different light conditions due to variations of water depth and position of the sun. The $\Phi_{\text {PSII }}$ decreased strongly during the ebb tide, essentially due to a drop in the maximal fluorescence level for light-adapted samples $\left(F_{\mathrm{m}}{ }^{\prime}\right)$. This was the result of increasing non-photochemical quenching (NPQ). Algae totally recovered during the rising tide, indicating that no significant photosynthetic damage occurred at ebb tide. L. saccharina responded to high light stress with photoprotective processes such as the xanthophyll cycle. The de-epoxidation ratio (DR) (i.e. conversion of violaxanthin into antheraxanthin and zeaxanthin) increased during the ebb tide and decreased during the rising tide. However, in spite of the development of a photoprotective mechanism, the overall photosynthetic activity (rETR) declined strongly at the highest irradiance level. This result indicates that primary production levels have been overestimated in the past.
\end{abstract}

KEY WORDS: Laminaria saccharina $\cdot$ Photoprotection · Xanthophyll cycle · Chlorophyll fluorescence · Diurnal tidal cycles · Diving PAM

Resale or republication not permitted without written consent of the publisher

\section{INTRODUCTION}

Laminariales are among the most abundant macroalgae in the upper subtidal zone of rocky shores in Northern France. They are located in a large belt between $6 \mathrm{~m}$ below and $2 \mathrm{~m}$ above bathymetrical zero. However, laminarian stocks, especially Laminaria digitata and L. saccharina have been decreasing in the last few years (Cosson 1999, Arzel 2000) for reasons that are not understood. This decrease leads to economic problems, as laminariales are used either as food or, more significantly, for the industrial extraction

*Email: francois.gevaert@univ-lille1.fr of valuable compounds such as alginate, laminarin, mannitol and iodine. To understand this decrease, the physiological behaviour that results from environmental variations or stresses needs to be explored in more detail.

Laminaria is sessile, attached by holdfasts in the intertidal or upper subtidal zones. It is exposed to considerable variations in irradiance because of (1) continuously changing water depth during the tidal cycle, and (2) natural variations in irradiance caused by weather conditions and by the sun's changing position during the day (Dring \& Lüning 1994). At our study site 
(Brittany), tides are semidiurnal; during spring tides, the low tide is around midday and thus coincides with maximal ambient irradiance. Laminaria acclimated to low irradiance are then exposed to high incident light levels. Exposure to excessive irradiance may lead to photoinhibition in macroalgae, reducing photosynthetic efficiency but avoiding, in most cases, photooxidative damage (Hanelt et al. 1993, 1997, Bruhn \& Gerard 1996, Schofield et al. 1998, Ensminger et al. 2000, Rodrigues et al. 2000). Under such circumstances, algae are able to develop protective mechanisms that dissipate excess excitation energy as heat. This phenomenon could be partially controlled by the xanthophyll cycle, which consists of the de-epoxidation of violaxanthin to, first, antheraxanthin, and then zeaxanthin (Demmig-Adams \& Adams 1996). The alga's xanthophyll cycle is triggered by light stress, as shown in green macroalgae by Ensminger et al. (2000), in brown macroalgae by Uhrmacher et al. (1995) and Schofield et al. (1998), and in L. saccharina in in vitro experiments by Duval et al. (1992), Benet et al. (1994), Harker et al. (1999), and Gévaert et al. (2002).

The photosynthetic performance of several marine macroalgae has been estimated using oxygen exchange, and more recently in the field, using a portable pulse amplitude modulated (PAM) fluorometer. This instrument provides information such as quantum yield, relative electron transport rate (rETR), and photochemical and non-photochemical quenching (NPQ). Using this technique, Hanelt et al. (1997) showed that gametophytes and old sporophytes of Laminaria saccharina are less sensitive to high light levels than younger thalli. Harker et al. (1999) showed that L. saccharina can develop NPQ of fluorescence, correlated with an increase in the de-epoxidation ratio (DR) of violaxanthin to zeaxanthin. Nevertheless, experimental irradiances used in that study were higher than the highest irradiances found in the field. No study has been done in situ to investigate the photosynthetic responses of $L$. saccharina to light variation and the development of photoprotective mechanisms during a tidal cycle. A recently developed submersible PAM fluorometer (Diving PAM, Walz) has been used to study in situ photosynthesis in seagrass (Ralph et al. 1998, Beer \& Björk 2000), sponges (Beer \& Ilan 1998) and corals (Beer et al. 1998, Jones \& HoeghGuldberg 2001), but not in seaweeds.

In this study, a series of in situ measurements were undertaken using the Diving PAM to determine whether Laminaria saccharina growing in the upper subtidal zone on rocky shores of Northern Brittany are sensitive to photoinhibition during a tidal cycle, and whether they are able to develop photoprotective mechanisms such as the xanthophyll cycle. To this end, experiments were carried out at ambient light, temperature and water conditions.

\section{MATERIALS AND METHODS}

Experiments were carried out on the brown kelp Laminaria saccharina (Lamouroux) in the upper subtidal zone of a Northern Brittany rocky shore near Roscoff (France) during the spring tide of September 2000. A total of 8 sporophytes with blade lengths of about $1 \mathrm{~m}$ were marked the day before the experiment with a coloured thread attached to their stipe. Fluorescence parameters were followed during the tidal cycle for 3 of these 8 sporophytes; 3 other thalli were used for pigment analysis and 2 other thalli were used to estimate photosynthetic parameters from rapid light curves (i.e. rETR variations vs increasing irradiance).

The seawater temperature during the experiment was about $16^{\circ} \mathrm{C}$. Photosynthetically active radiation (PAR) was measured in air during the tidal cycle (1 measurement every $15 \mathrm{~s}$, averaged over $1 \mathrm{~min}$ ) using an SA-190 quantum sensor connected to a datalogger (Li-Cor, Li-1400). In situ ambient radiation was measured underwater close to the algae with the Diving PAM quantum sensor, calibrated in air with the SA-190 light meter.

Fluorescence measurements. In vivo chlorophyll fluorescence properties were measured in situ by SCUBA divers using a submersible PAM fluorometer. The fluorescence signal was always taken from the middle of the frond in the same place for 3 sporophytes. Thalli were dark-adapted for 5 min using the 'Dark Leaf Clip Diving L-C' (Walz) to which the fiber optic of the fluorometer was applied and maintained to perform each measurement. First, the initial fluorescence $\left(F_{0}\right)$ was induced by the low irradiance of the red measuring light, and maximal fluorescence $\left(F_{\mathrm{m}}\right)$ was determined following a single saturating light pulse $(0.8 \mathrm{~s})$. Variable fluorescence $\left(F_{\mathrm{v}}\right)$ was calculated as the difference between $F_{\mathrm{m}}$ and $F_{0}$. The optimal quantum yield was calculated as $F_{\mathrm{v}} / F_{\mathrm{m}}$. After these initial measurements, the effective quantum yield of photosystem II $\left(\Phi_{\text {PSII }}\right)$ was followed on the 3 sporophytes at 5 stages of the tidal cycle: $\mathrm{S}_{1}$ and $\mathrm{S}_{2}$ during the ebb tide (algae at 5.4 and $3.1 \mathrm{~m}$ depth, respectively), $\mathrm{S}_{3}$ at low tide (1.6 $\mathrm{m}$ depth), and $\mathrm{S}_{4}$ and $\mathrm{S}_{5}$ during the rising tide (4.2 and $8.4 \mathrm{~m}$ depth, respectively). In contrast to $F_{\mathrm{v}} / F_{\mathrm{m}}$, $\Phi_{\text {PSII }}$ was measured under ambient light. The fiber optic was mounted in a home-made transparent Plexiglas holder applied to one side of the thallus in such a way that the distance between the fiber optic and the algal tissue was constant and standard. The fiber optic forms a $60^{\circ}$ angle with the sample, avoiding awkward shading or darkening.

$\Phi_{\text {PSII }}$ was calculated as $\left(F_{\mathrm{m}}{ }^{\prime}-F_{\mathrm{t}}\right) / F_{\mathrm{m}}{ }^{\prime}$ (Genty et al. 1989), where $F_{\mathrm{m}}{ }^{\prime}$ is the maximal fluorescence level measured during a single saturating light pulse $(0.8 \mathrm{~s})$ for light-adapted samples, and $F_{\mathrm{t}}$ is the fluorescence 
steady-state level immediately prior to the flash. Then, the apparent photosynthetic rETR was estimated according to Genty et al. (1989) using the following equation:

$$
\mathrm{rETR}=\Phi_{\mathrm{PSII}} \times \mathrm{PPFD} \times 0.5
$$

where PPFD (PAR photon flux density) is the value of the actinic light (directly measured close to the sample by the Diving PAM quantum sensor, which was also fixed to the holder), and 0.5 is a correction factor based on the assumption that the incident photons are absorbed equally by the pigments of the 2 photosystems.

Rapid light curves. Rapid light curves were also determined with the Diving PAM in 2 other Laminaria saccharina thalli at $\mathrm{S}_{1}, \mathrm{~S}_{3}$ and $\mathrm{S}_{5}$ (beginning of the ebb tide, low tide, and end of the flood tide, respectively). They were generated by applying and maintaining the light guide of the Diving PAM on the thalli via the Dark Leaf Clip. The initial $F_{0}$ and $F_{\mathrm{m}}$ were measured after 5 min darkness as described above for each sporophyte before monitoring commenced. The algae were then exposed to 8 steps (10 s each) of increasing artificial actinic light from the internal light source of the Diving PAM. The fluorescence parameters were measured using an automatic run and $\Phi_{\text {PSII }}$ rETR and NPQ were calculated at each step. The apparent photosynthetic rETR was calculated as described above, but in this case as a function of the artificial actinic light provided by the internal light source of the Diving PAM. We checked that the irradiance of the internal light source did not decrease over the whole series of measurements by recording the light intensities (using an SA-190 light meter) during 6 rapid light curves (corresponding to our experiments) and used the averaged values of these measurements: 10, 40, 79, 150, 234, $333,513,715 \mu \mathrm{mol}$ quanta $\mathrm{m}^{-2} \mathrm{~s}^{-1}$. The irradiation period (10 s) and the number of replicates and stages were limited by the power of the battery in the Diving PAM.

NPQ, which correlates positively and linearly to energy dissipation as heat, was calculated according to Bilger \& Björkman (1990):

$$
\mathrm{NPQ}=\frac{F_{\mathrm{m}}-F_{\mathrm{m}}{ }^{\prime}}{F_{\mathrm{m}}{ }^{\prime}}
$$

where $F_{\mathrm{m}}$ is the maximum fluorescence for each sporophyte at the beginning of the experiment (at $S_{1}$ ).

Photosynthetic parameters, i.e. maximum rETR $\left(\mathrm{rETR}_{\mathrm{m}}\right)$, initial slope of the non-saturated photosynthetic rate $\left(\alpha_{\mathrm{I}}\right)$, saturation onset parameter $\left(I_{\mathrm{k}}\right)$ and irradiance for $\mathrm{rETR}_{\mathrm{m}}\left(I_{\mathrm{m}}\right)$ were estimated from the rapid light curves using the model described by Eilers \& Peeters (1988).

Pigments analysis. Thallus disks (8 $\mathrm{mm}$ diameter) were sampled at the 5 stages of the tidal cycle $\left(\mathrm{S}_{1}\right.$ to $\left.\mathrm{S}_{5}\right)$ from 3 separate thalli. The disk samples were immediately frozen and kept in liquid nitrogen until pigment extraction and analysis by HPLC in the laboratory. Before the extraction, epiphytic diatoms were removed by rinsing the samples with distilled water and drying with filter paper. Samples were then ground in a mortar with methanol under dim light. Following extraction, homogenates were centrifuged at $15000 \times g$ for $5 \mathrm{~min}$. Supernatants were filtered on PTFE Millex membrane $(0.45 \mu \mathrm{m})$ (Millipore) and dried under a stream of nitrogen. Pigments were extracted with a mixture of methylene chloride/distilled water (50/50 v/v) and after decanting, the non-pigmented aqueous phase was discarded to remove the salt. The pigment phase was then evaporated under a stream of nitrogen and recovered with methanol for injection.

Reversed-phase HPLC was performed according to Arsalane et al. (1994) using a Waters system equipped with a 1091 diode array detector on a Zorbax ODS column $(25.0 \mathrm{~cm} \times 4.6 \mathrm{~mm}, 5 \mu \mathrm{m}$ particles $)$. Extinction coefficients used for external calibration of our system were as in Berkaloff et al. (1990). The xanthophyll cycle DR, determined at the different stages of the tidal cycle, was calculated as:

$$
\mathrm{DR}=\frac{A+Z}{V+A+Z}
$$

where $V, A$, and $Z$ are violaxanthin, antheraxanthin and zeaxanthin concentration, respectively (moles per 100 moles chlorophyll a).

\section{RESULTS}

\section{Time course of light}

The experiment was performed under mostly clear sky with some irregular occurrence of clouds. Irradiance gradually increased during the morning, reached its maximum value at 14:00 $\mathrm{h}(\mathrm{UT}+2)$ and then progressively declined until sunset (Fig. 1). Maximum irradiance thereby corresponded to the period of low tide (about 13:30 h) when algae were at $1.6 \mathrm{~m}$ depth; this is commonly the case during spring tides in Northern Britanny. During this period, algae were therefore subjected to rather high irradiances of $559 \mu \mathrm{mol}$ quanta $\mathrm{m}^{-2} \mathrm{~s}^{-1}$.

\section{Time course of fluorescence parameters}

The mean $F_{\mathrm{v}} / F_{\mathrm{m}}$, determined at the beginning of the experiment, was $0.74 \pm 0.01$ (mean \pm SD). Fig. 2 illustrates the time course of the mean effective quantum yield $\left(\Phi_{\text {PSII }}\right)$ in Laminaria saccharina measured under- 
water. During the ebb tide, $\Phi_{\text {PSII }}$ declined by $82 \%$, essentially due to decreases in the $F_{\mathrm{m}}$ ' values (data not shown). This illustrates the initiation of the NPQ increase and photoprotective reactions during the ebb tide. However, during the rising tide, the $\Phi_{\mathrm{PSII}}$ returned to the initial value, as the thalli recovered their photosynthetic efficiency. The PSII of L. saccharina did not appear to be irreversibly damaged at low tide. A significant negative linear correlation was observed between $\Phi_{\text {PSII }}$ levels and the corresponding underwater irradiances:

$$
\begin{gathered}
\Phi_{\text {PSII }}=0.660-0.001 \times(\text { underwater irradiance }) \\
\mathrm{r}=0.822, \mathrm{n}=15, \mathrm{p}<0.001
\end{gathered}
$$

In order to follow more precisely the overall photosynthetic capacity of Laminaria saccharina during the tidal cycle we calculated the rETR (Fig. 3). The mean rETR increased during the ebb tide with the increase in irradiance measured at the surface of the thallus and reached its maximum value at midday (irradiance at the thallus surface: $309 \mu \mathrm{mol}$ quanta $\mathrm{m}^{-2}$ $\left.\mathrm{s}^{-1}\right)$. However, with maximum irradiance (559 $\mu \mathrm{mol}$ quanta $\mathrm{m}^{-2} \mathrm{~s}^{-1}$ ) at low tide, the rETR was only half of the previous value. The rETR subsequently continued to decrease with decreasing irradiance until sunset.

\section{Time course of pigment content}

During the ebb tide, violaxanthin was progressively converted into zeaxanthin, and DR increased from 0.100 to 0.213 at low tide (Fig. 4). During the rising tide, the DR returned to about the initial value. The amounts of other pigments (chlorophyll $C_{\text {, }}$ fucoxanthin, chlorophyll $a$ and $\beta$ carotene) did not change (data not shown).

A significant negative linear correlation was observed between the effective quantum yields of PSII and DR:

$$
\begin{gathered}
\mathrm{DR}=0.231-0.225 \Phi_{\text {PSII }} \\
\mathrm{r}=0.773, \mathrm{n}=15, \mathrm{p}<0.001
\end{gathered}
$$

\section{Rapid light curves}

Fig. 5 shows the variation in rETR versus irradiance ( $\mu \mathrm{mol}$ quanta $\mathrm{m}^{-2} \mathrm{~s}^{-1}$ ) in 2 sporophytes at 3 different tidal stages, and corresponding curves obtained by fitting the data to the model of Eilers \& Peeters (1988). The photosynthetic parameters at the 3 stages of the tidal cycle are given in Table 1 . Whereas $\alpha_{\mathrm{I}}$ and $I_{\mathrm{k}}$ did not vary significantly in the course of the tide (Kruskal-Wallis test: $H_{\mathrm{c}}=4.191, \mathrm{p}=0.123$ and $H_{\mathrm{c}}=3.714, \mathrm{p}=0.156$, respectively; $\mathrm{n}_{1}=2, \mathrm{n}_{2}=2, \mathrm{n}_{3}=2$ ), $\mathrm{rETR}_{\mathrm{m}}$ and $I_{\mathrm{m}}$ values were significantly higher at $\mathrm{S}_{1}$ than at $\mathrm{S}_{5}$ but lower than at $\mathrm{S}_{3}$ (Kruskal-Wallis test: $H_{\mathrm{c}}=4.571$; $\mathrm{p}=0.102$, the lowest significant probability available for $\mathrm{n}_{1}=2$, $\mathrm{n}_{2}=2, \mathrm{n}_{3}=2$ and obtained with the most favorable case corresponding to a complete separation of each pair within the 3 groups $\mathrm{S}_{1}, \mathrm{~S}_{3}$ and $\mathrm{S}_{5}$ ). At low tide, $\mathrm{rETR}_{\mathrm{m}}$ was $49 \pm 3$ (mean \pm SD) and $I_{\mathrm{m}}, 427 \pm 18 \mu \mathrm{mol}$ quanta $\mathrm{m}^{-2} \mathrm{~s}^{-1}$. NPQ curves for sporophytes 1 and 2 are pre-

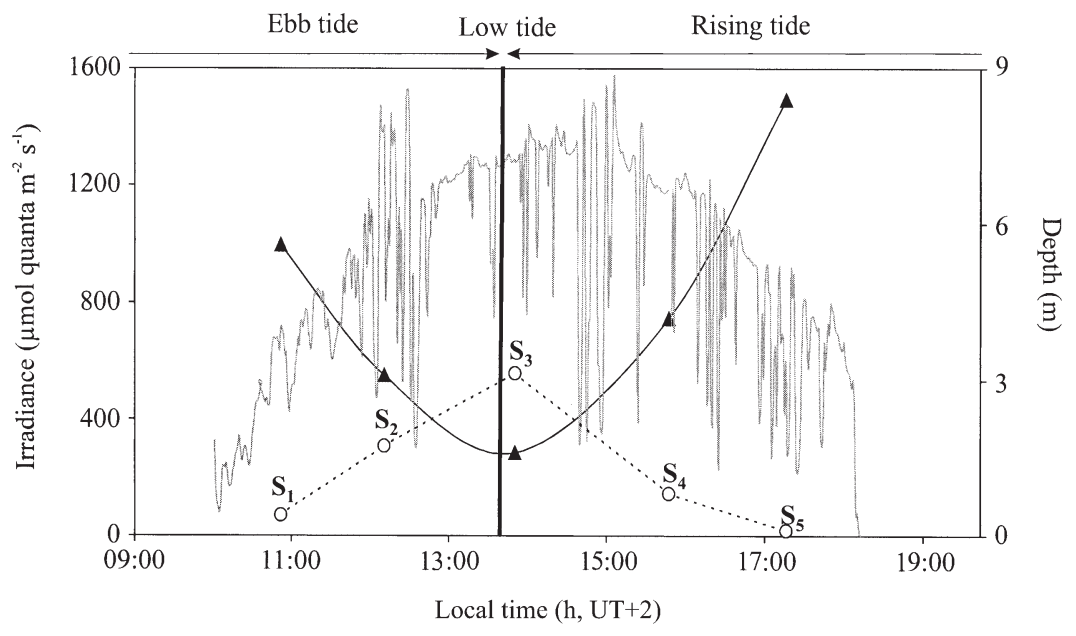

Fig. 1. Diurnal course of incident irradiance (PAR, solid line), underwater

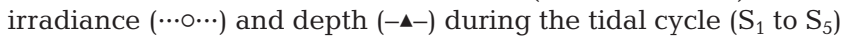

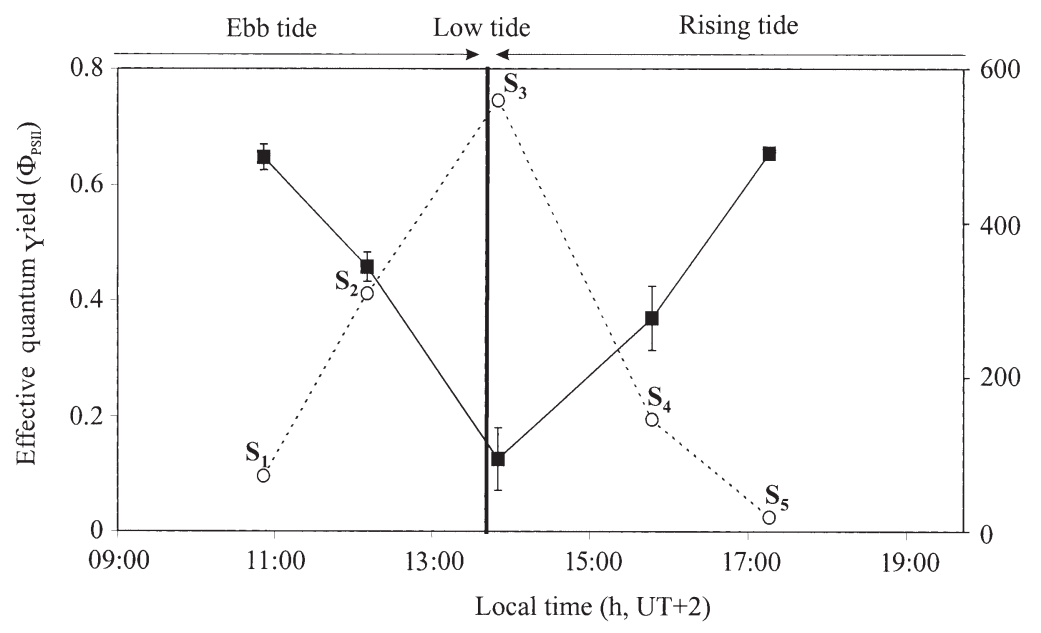

Fig. 2. Laminaria saccharina. Diurnal course of mean effective quantum yield $\left(\Phi_{\text {PSII }}\right)$ measured in 3 sporophytes during the 5 stages of the tidal cycle, $\mathrm{S}_{1}$ to $\mathrm{S}_{5}\left(--_{-}\right.$i vertical bars: $\left.\mathrm{SD}\right)$ and underwater irradiance measured at the surface of the algae $(\cdots \circ \cdots)$ 
sented in Fig. 6. NPQ values increased progressively with the irradiance applied regardless of the state of the tide, but nevertheless remained relatively low. The NPQ values during the rising tide $\left(\mathrm{S}_{5}\right)$ were significantly lower than at low tide $\left(\mathrm{S}_{3}\right)$, but higher than at ebb tide $\left(\mathrm{S}_{1}\right)$ (1-way ANOVA: $F$-ratio $=276.85, \mathrm{p}<0.001, \mathrm{n}=48$; Tukey post-hoc test: $\mathrm{p}<0.001$ between $\mathrm{S}_{1}$ and $S_{3}$, as well as $S_{1}$ and $S_{5}$, and $S_{3}$ and $\left.\mathrm{S}_{5}\right)$. At the beginning of the ebb tide $\left(\mathrm{S}_{1}\right)$, Laminaria saccharina developed negligible thermal energy dissipation, regardless of the irradiance applied.

\section{DISCUSSION}

Laminaria saccharina has been the subject of physiological and ecological studies which have led to a better understanding of the maintenance of ecologically important $L$. saccharina populations in many different environments (water depth and latitude), but all have been carried out in the laboratory, either on cultivated L. saccharina or on collected algae which could have been subject to stress due to the treatment. We considered that it was important to follow the light variations to which $L$. saccharina can be subject during diurnal tidal cycles and to study their physiological responses in situ.

The seaweeds studied were located at a rather high shore level $(1.6 \mathrm{~m}$ depth at low tide). Nevertheless, the thalli never emerged and therefore never experienced full solar radiation or desiccation.

The optimal quantum yield, a measure widely used to assess the importance of light stress, was first calculated from $F_{\mathrm{v}} / F_{\mathrm{m}}$ of dark-adapted Laminaria saccharina

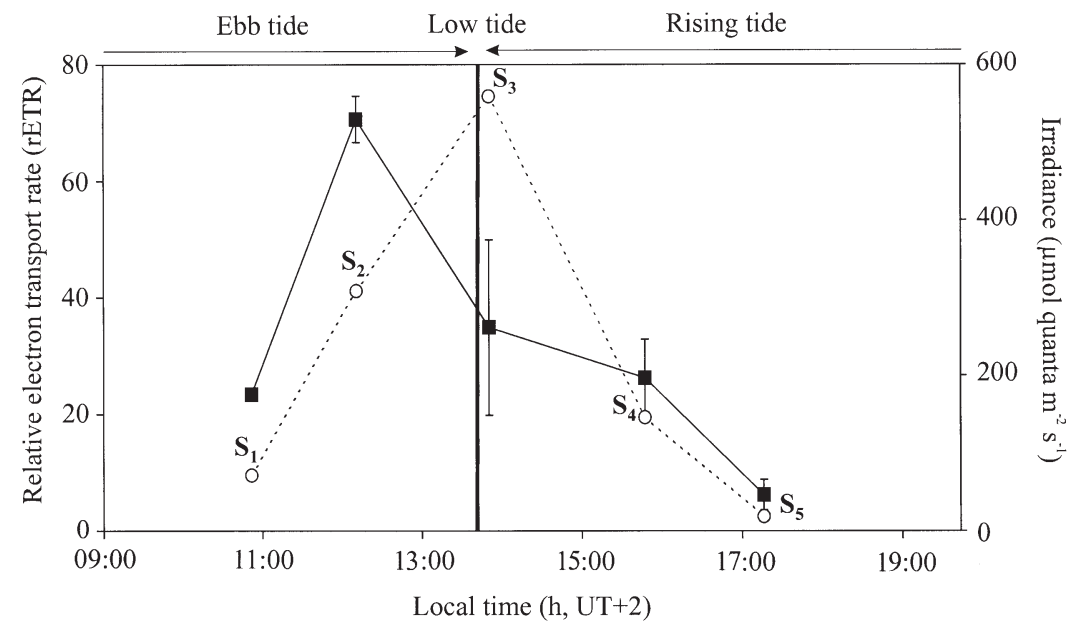

Fig. 3. Laminaria saccharina. Diurnal course of mean relative electron transport rate (rETR) measured in 3 sporophytes during the 5 stages of the tidal cycle, $\mathrm{S}_{1}$ to $\mathrm{S}_{5}(--$; vertical bars: $\mathrm{SD})$ and underwater irradiance measured at the surface of the algae $(\cdots \circ \cdots)$

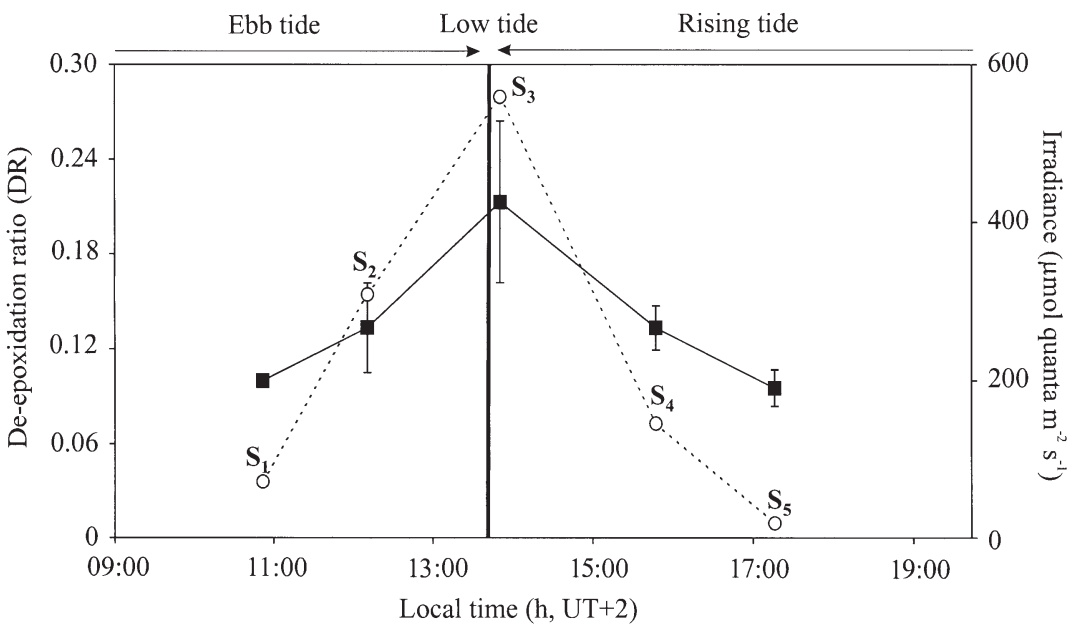

Fig. 4. Laminaria saccharina. Diurnal course of mean de-epoxidation ratio (DR) measured in 3 sporophytes during the 5 stages of the tidal cycle, $\mathrm{S}_{1}$ to $\mathrm{S}_{5}(--$; vertical bars: $\mathrm{SD})$ and underwater irradiance measured at the surface of the algae $(\cdots \circ \cdots)$

Table 1. Laminaria saccharina. Photosynthetic parameters assessed with the model of Eilers \& Peeters (1988) at different stages of the tidal cycle, measured in 2 sporophytes (8 levels of irradiance). $\alpha_{I}=$ initial slope of the photosynthetic rate; $\mathrm{rETR}_{\mathrm{m}}=$ maximum relative electron transport rate $I_{\mathrm{k}}=$ saturation onset parameter; $I_{\mathrm{m}}=$ irradiance for $\mathrm{rETR}_{\mathrm{m}} . \mathrm{r}^{2}=0.998$ to 0.999 in all cases

\begin{tabular}{|lcrrrr|}
\hline $\begin{array}{l}\text { Stage of the } \\
\text { tidal cycle }\end{array}$ & $\begin{array}{c}\text { Depth } \\
(\mathrm{m})\end{array}$ & $\alpha_{\mathrm{I}}$ & $\mathrm{rETR}_{\mathrm{m}}$ & $\begin{array}{c}I_{\mathrm{k}} \\
\left(\mu \mathrm{mol} \mathrm{m}^{-2} \mathrm{~s}^{-1}\right)\end{array}$ & $\begin{array}{c}I_{\mathrm{m}} \\
\left(\mu \mathrm{mol} \mathrm{m}^{-2} \mathrm{~s}^{-1}\right)\end{array}$ \\
\hline Ebbing tide $\left(\mathrm{S}_{1}\right)$ & 5.6 & $0.48(0.43-0.53)$ & $28.5(26-31)$ & $60(49-72)$ & $203.5(203-204)$ \\
Low tide $\left(\mathrm{S}_{3}\right)$ & 1.6 & $0.23(0.22-0.24)$ & $49(47-51)$ & $215(212-218)$ & $427(414-440)$ \\
Rising tide $\left(\mathrm{S}_{5}\right)$ & 8.4 & $0.42(0.41-0.43)$ & $19(18-20)$ & $46(43-50)$ & $161(146-176)$ \\
\hline
\end{tabular}




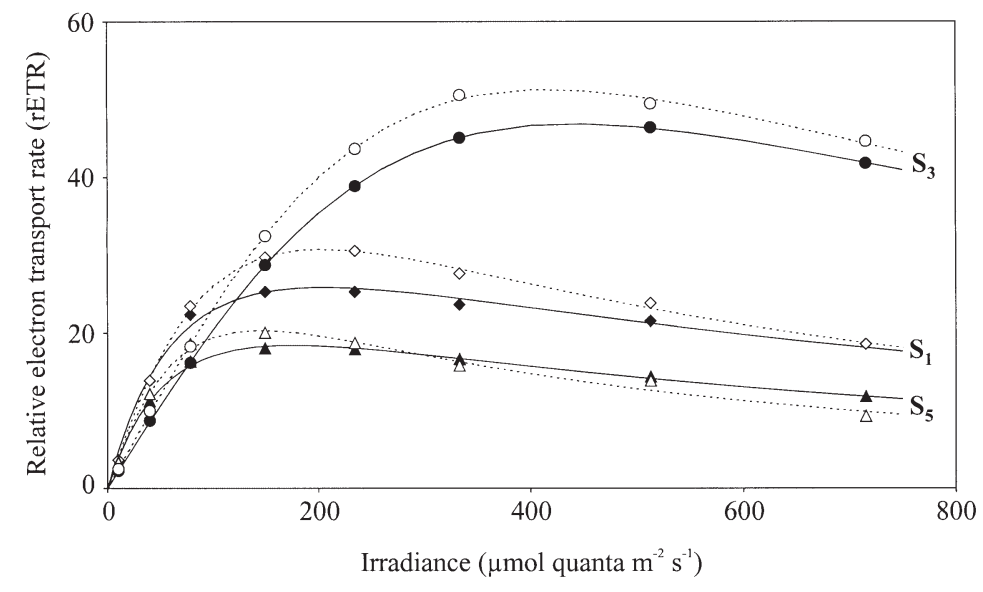

Fig. 5. Laminaria saccharina. Rapid light curves, expressed as relative electron transport rate (rETR) at different stages of the tidal cycle, $\mathrm{S}_{1}, \mathrm{~S}_{3}$ and $S_{5}$. Black symbols and solid line: sporophyte 1 , open symbols and dotted line: sporophyte 2. Data are fitted to the model of Eilers \& Peeters (1988)
$F_{\mathrm{m}}{ }^{\prime}$ which could be the result of an increasing NPQ. Recovery was complete at the end of the rising tide, contrary to laboratory experiments (Bruhn \& Gerard 1996). The diurnal course of the effective quantum yield ( $\left.\Phi_{\mathrm{PSII}}\right)$ was directly correlated to underwater irradiance. The rapid recovery of the quantum yield suggested that the responses of Laminaria saccharina to high light intensity are linked to a down-regulation of PSII (now usually termed 'dynamic photoinhibition') rather than to the onset of photosynthetic damage ('chronic photoinhibition'), which reduces photosynthesis for longer periods (Henley et al. 1991, Osmond \& Grace 1995, Jones \& Hoegh-Guldberg 2001, Werner et al. 2001). Photoprotection after exposure to solar radiation has been observed in other macroalgae (Hanelt et al. 1997, Ensminger et al. 2000, Rodrigues et al. 2000). It occurs when light energy input exceeds the capacity for energy thalli in the morning. The high value, about 0.75 is commonly obtained with brown macroalgae (Büchel \& Wilhelm 1993, Dring et al. 1996) and indicated that the algae were photochemically efficient despite exposure to 4 successive sunny days during the spring tide, suggesting that they were acclimated to high light.

Increasing light during the ebb tide (due both to the ambient light increase during the morning and to decreasing water depth) led to an immediate decrease in photosynthetic quantum yield, and the seaweeds responded to the maximum light (559 $\mu \mathrm{mol}$ quanta $\mathrm{m}^{-2}$ $\mathrm{s}^{-1}$ ) by a $82 \%$ reduction in the effective quantum yield (Fig. 2). The reduction is essentially due to the drop in

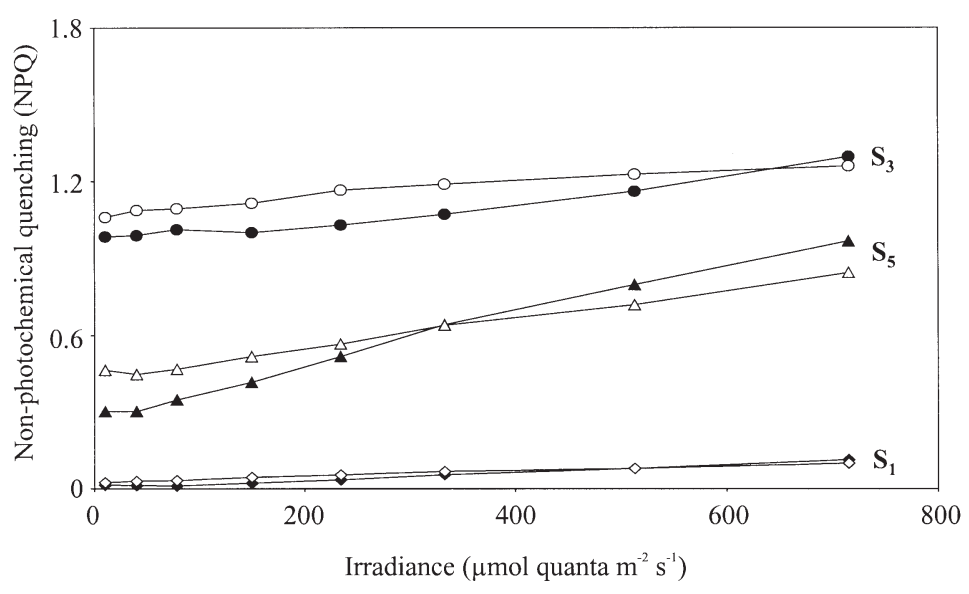

Fig. 6. Laminaria saccharina. Changes in non-photochemical quenching (NPQ) in response to increased irradiance. NPQ was calculated from the fluorescence parameters of the rapid light curves at different stages of the tidal cycle: $\mathrm{S}_{1}, \mathrm{~S}_{3}$ and $\mathrm{S}_{5}$. Black symbols: sporophyte 1 , open symbols: sporophyte 2 excess excitation energy in the pigment antenna of PSII. This regulatory process is still not fully understood, but it is known to limit accumulation of reactive oxygen species, protecting algae against photo-oxidative damage.

Several mechanisms in algae divert excess energy. First, they are able to reduce absorption by rearranging the chloroplasts into a low-absorbing position (Hanelt \& Nultsch 1991). Moreover, older, thicker sporophytes are more resistant to high light than younger, thinner thalli (Hanelt et al. 1997). In this way, the chloroplasts could be protected by increasing selfshading. When these mechanisms are insufficient to avoid excess energy absorption, algae and higher plants may develop a photoprotective process such as the xanthophyll cycle, resulting in thermal energy dissipation. It involves the de-epoxidation of violaxanthin to antheraxanthin and zeaxanthin (Demmig-Adams \& Adams 1996).

Bruhn \& Gerard (1996) studied the xanthophyll cycle during high light stress treatments on Laminaria saccharina. They found that the photoinhibition responses are not affected in the presence of the inhibitor dithiothreitol (DTT), but that recovery from photoinhibition is slower. In our experiment, DR varied during the tidal cycle as shown in Fig. 4: it increased during the ebb tide, then decreased during the rising tide. We show here that in L. saccharina, the xanthophyll cycle occurs in situ during the tidal utilization and usually results in thermal dissipation of reached its maximal value at low tide and 
cycle and that its development is directly correlated with the daily course of effective quantum yield. However, the converted pool of violaxanthin is rather low (about $21 \%$ ) in comparison to the conversion ratio $(60 \%)$ in Lobophora variegata in coral reefs (Franklin et al. 1996), but our data are in agreement with the results obtained during photoinhibition of Cladophora glomerata (Ensminger et al. 2000). Harker et al. (1999) obtained an in vitro DR of 0.41 when L. saccharina were submitted to $450 \mu \mathrm{mol}$ quanta $\mathrm{m}^{-2} \mathrm{~s}^{-1}$ for $45 \mathrm{~min}$, which caused photoinhibition by suppression of oxygen evolution (Lemoine et al. 1995).

The initial DR in our study is quite high (0.1) suggesting that zeaxanthin and antheraxanthin are an important protection against high light stress, or that some conversion occurred even when irradiance was low $\left(72 \mu \mathrm{mol}\right.$ quanta $\left.\mathrm{m}^{-2} \mathrm{~s}^{-1}\right)$. The DR obtained in vitro by Harker et al. (1999) in dark incubated Laminaria saccharina was 0.07 , similar to our in situ initial value.

The rETR increased during the morning ebb tide, indicating increasing photon capture, but it decreased sharply at the low tide peak of light, and then slowly declined with falling PPFD during the afternoon rising tide, showing that Laminaria saccharina can undergo photoinhibition of photosynthetic efficiency and performance under midday low tide irradiance conditions.

Rapid light curves measured at early ebb tide $\left(\mathrm{S}_{1}\right)$, low tide $\left(\mathrm{S}_{3}\right)$ and the later rising tide $\left(\mathrm{S}_{5}\right)$ allowed us to determine photosynthetic response to light variations. At $\mathrm{S}_{3}$, Laminaria saccharina exhibited photosynthetic characteristics of high light adapted algae. At this stage, the $\mathrm{rETR}_{\mathrm{m}}$ was double the values obtained at $\mathrm{S}_{1}$ and $\mathrm{S}_{5}$. These results are consistent with those obtained for the daily rETR variation (Fig. 3), i.e. the rETR value was higher in $S_{3}$ than in $S_{1}$ and $S_{5}$. It would have been interesting to conduct a rapid light curve at $S_{2}$ when the rETR of the diurnal course was at its maximum.

An increased photosynthetic rate is typically observed with acclimation to higher irradiance (Henley 1993). The increase in $\mathrm{ETR}_{\mathrm{m}}$ indicates an activation of photosynthesis, most likely via increased rate of 'dark' carbon-fixing enzymes such as RUBISCO. This is a common phenomenon in macrophytes. Similar activation and increased ETR is also seen in corals (Ralph et al. 1999). Some differences were observed in measures of photosynthetic activity $\left(\mathrm{rETR}_{\mathrm{m}}\right.$ and $\left.I_{\mathrm{m}}\right)$ between $\mathrm{S}_{1}$ and $\mathrm{S}_{5}$ (cf. Table 1). They could be due to the differences in depth and irradiance: at $\mathrm{S}_{1}$ the depth was $5.4 \mathrm{~m}$ and irradiance was $72 \mu \mathrm{mol}$ quanta $\mathrm{m}^{-2} \mathrm{~s}^{-1}$, and at $\mathrm{S}_{5}$ the depth was $8.4 \mathrm{~m}$ and irradiance was $19 \mu \mathrm{mol} \mathrm{m}{ }^{-2} \mathrm{~s}^{-1}$. Variations of NPQ calculated from the fluorescence parameters during the rapid light curves at $\mathrm{S}_{1}, \mathrm{~S}_{3}$ and $\mathrm{S}_{5}$ agree with the values of $\Phi_{\mathrm{PSII}}$ and DR (Figs. 2 \& 4 respectively): under strong light at low tide
$\left(\mathrm{S}_{3}\right)$, Laminaria saccharina exhibited the highest $\mathrm{NPQ}$, consistent with the lowest $\Phi_{\text {PSII }}$ value (Fig. 2) and highest DR value (Fig. 4). The response of the algae at $S_{1}$, i.e. a low $N P Q$, suggests that they were not adapted to high light and therefore not able to develop a high NPQ.

In conclusion, in situ experiments demonstrated that Laminaria saccharina is strongly photoinhibited at ebb tide and fully recovers its photosynthetic capacities during the rising tide, because it has developed photoprotective mechanisms such as the xanthophyll cycle during periods of light stress. However, the strong decrease in rETR at the highest irradiance level should be taken into account in estimates of primary production.

Acknowledgements. Funding was provided by the French Program PNEC (Programme National Environnement Côtier). The authors thank the divers of Station Biologique of Roscoff and C. Gévaert for their technical assistance. F.G. thanks the Centre National de la Recherche Scientifique (CNRS) and the Région Nord-Pas-de-Calais for a doctoral fellowship. We are also grateful to A. Rees and V. Pasour for improving the language of the manuscript.

\section{LITERATURE CITED}

Arsalane W, Rousseau B, Duval JC (1994) Influence of the pool size of the xanthophyll cycle on the effect of light stress in a diatom: competition between photoprotection and photoinhibition. Photochem Photobiol 60:237-243

Arzel P (2000) Revue des causes de variations de l'abondance du champ de laminaires. In: Nonnotte G, Sébert $P$, Devauchelle N (eds) Le milieu aquatique: interactions des facteurs environnementaux et impacts sur les organismes vivants. Colloque de la Société d'Ecophysiologie et de la Société d'Ichthyophysiologie Fondamentale et Appliquée. Anaximandre, Lesneven, p 10-16

Beer S, Björk M (2000) Measuring rates of photosynthesis of two tropical seagrasses by pulse amplitude modulated (PAM) fluorometry. Aquat Bot 66:69-76

Beer S, Ilan M (1998) In situ measurements of photosynthetic irradiance responses of two Red Sea sponges growing under dim light conditions. Mar Biol 131:613-617

Beer S, Ilan M, Eshel A, Weil A, Brickner I (1998) Use of pulse amplitude modulated (PAM) fluorometry for in situ measurements of photosynthesis in two Red Sea faviid corals. Mar Biol 131:607-612

Benet H, Bruss U, Duval JC, Kloareg B (1994) Photosynthesis and photoinhibition in protoplasts of the marine brown alga Laminaria saccharina. J Exp Bot 45(271):211-220

Berkaloff C, Caron L, Rousseau B (1990) Subunit organization of PSI particles from brown algae and diatoms: polypeptides and pigment analysis. Photosynth Res 23:181-193

Bilger W, Björkman O (1990) Role of the xanthophyll cycle in photoprotection elucidated by measurements of the lightinduced absorbance changes, fluorescence and photosynthesis in leaves of Hedera canariensis. Photosynth Res 25: 173-185

Bruhn J, Gerard VA (1996) Photoinhibition and recovery of the kelp Laminaria saccharina at optimal and superoptimal temperatures. Mar Biol 125:639-648 
Büchel C, Wilhelm C (1993) In vivo analysis of slow chlorophyll fluorescence induction kinetics in algae: progress, problems and perspectives. Photochem Photobiol 58(1): $137-148$

Cosson J (1999) Sur la disparition progressive de Laminaria digitata sur les côtes du Calvados (France). Cryptogam Algol 20(1):35-42

Demmig-Adams B, Adams WWI (1996) The role of xanthophyll cycle carotenoids in the protection of photosynthesis. Trends Plant Sci 1(1):21-26

Dring MJ, Lüning K (1994) Influence of spring-neap tidal cycles on the light available for photosynthesis by benthic marine plants. Mar Ecol Prog Ser 104:131-137

Dring MJ, Makarov V, Schoschina E, Lorenz M, Lüning K (1996) Influence of ultraviolet-radiation on chlorophyll fluorescence and growth in different life-history stages of three species of Laminaria (Phaeophyta). Mar Biol 126:183-191

Duval JC, Harker M, Rousseau B, Young AJ, Britton G, Lemoine Y (1992) Photoinhibition and zeaxanthin formation in the brown algae Laminaria saccharina and Pelvetia canaliculata. In: Murata N (ed) Research in photosynthesis. Kluwer, Dordrecht, p 581-584

Eilers PHC, Peeters JCH (1988) A model for the relationship between light intensity and the rate of photosynthesis in phytoplankton. Ecol Model 42:199-215

Ensminger I, Hagen C, Braune W (2000) Strategies providing success in a variable habitat: II. Ecophysiology of photosynthesis of Cladophora glomerata. Plant Cell Environ 23: $1129-1136$

Franklin LA, Seaton GGR, Lovelock CE, Larkum AWD (1996) Photoinhibition of photosynthesis on a coral reef. Plant Cell Environ 19:825-836

Genty B, Briantais JM, Baker NR (1989) The relationship between the quantum yield of photosynthetic electron transport and quenching of chlorophyll fluorescence. Biochim Biophys Acta 990:87-92

Gévaert F, Créach A, Davoult D, Holl AC, Seuront L, Lemoine $Y$ (2002) Photo-inhibition and seasonal photosynthetic performance of the seaweed Laminaria saccharina during a simulated tidal cycle: chlorophyll fluorescence measurements and pigment analysis. Plant Cell Environ 25: 859-872

Hanelt D, Nultsch W (1991) The role of chromatophore arrangement in protecting the chromatophores of the brown alga Dictyota dichotoma against photodamage. J Plant Physiol 138:470-475

Hanelt D, Huppertz K, Nultsch W (1993) Daily course of photosynthesis and photoinhibition in marine macroalgae investigated in the laboratory and field. Mar Ecol Prog Ser 97:31-37

Hanelt D, Wiencke C, Karsten U, Nultsch W (1997) Photoinhi-

Editorial responsibility: Otto Kinne (Editor),

Oldendorf/Luhe, Germany bition and recovery after high light stress in different developmental and life-history stages of Laminaria saccharina (Phaeophyta). J Phycol 33:387-395

Harker M, Berkaloff C, Lemoine Y, Britton G, Young AJ, Duval JC, Rmiki NE, Rousseau B (1999) Effects of high light and dessication on the operation of the xanthophyll cycle in two marine brown algae. Eur J Phycol 34:35-42

Henley WJ (1993) Measurement and interpretation of photosynthetic light-response curves in algae in the context of photoinhibition and diel changes. J Phycol 29:729-739

Henley WJ, Levavasseur G, Franklin LA, Lindley ST, Ramus J, Osmond CB (1991) Diurnal responses of photosynthesis and fluorescence in Ulva rotundata acclimated to sun and shade in outdoor culture. Mar Ecol Prog Ser 75:19-28

Jones RJ, Hoegh-Guldberg O (2001) Diurnal changes in the photochemical efficiency of the symbiotic dinoflagellates (Dinophyceae) of corals: photoprotection, photoinactivation and the relationship to coral bleaching. Plant Cell Environ 24:89-99

Lemoine Y, Harker M, Rmiki NE, Rousseau B, Berkaloff C, Duval JC, Young AJ, Britton G (1995) Xanthophyll cycle operation and photoprotection in brown algae: effects of high light and dessication. In: Mathis P (ed) Photosynthesis: from light to biosphere. Kluwer, Dordrecht, p 119-122

Osmond CB, Grace SC (1995) Perspectives on photoinhibition and photorespiration in the field: quintessential inefficiencies of the light and dark reactions of photosynthesis? J Exp Bot 46:1351-1362

Ralph PJ, Gademann R, Dennison WC (1998) In situ seagrass photosynthesis measured using a submersible, pulseamplitude modulated fluorometer. Mar Biol 132:367-373

Ralph PJ, Gademann R, Larkum AWD, Schreiber U (1999) In situ underwater measurement of photosynthetic activity of coral zooxanthellae and other reef-dwelling dinoflagellate endosymbionts. Mar Ecol Prog Ser 180:139-147

Rodrigues MA, dos Santos CP, Yoneshigue-Valentin Y, Strbac D, Hall DO (2000) Photosynthetic light-response curves and photoinhibition of the deep-water Laminaria abyssalis and the intertidal Laminaria digitata (Phaeophyceae). J Phycol 36:97-106

Schofield O, Evens TJ, Millie DF (1998) Photosystem II quantum yields and xanthophyll-cycle pigments of the macroalga Sargassum natans (Phaeophyceae): responses under natural sunlight. J Phycol 34:104-112

Uhrmacher S, Hanelt D, Nultsch W (1995) Zeaxanthin content and the degree of photoinhibition are linearly correlated in the brown alga Dictyota dichotoma. Mar Biol 123: 159-165

Werner C, Ryel RJ, Correia O, Beyschlag W (2001) Effects of photoinhibition on whole-plant carbon gain assessed with a photosynthesis model. Plant Cell Environ 24:27-40

Submitted: January 17, 2002; Accepted: July 26, 2002

Proofs received from author(s): January 6, 2003 